\title{
After the Fall: Lessons for Policy Cooperation from the Global Crisis
}

Tamim Bayoumi 


\title{
IMF Working Paper
}

Strategy, Policy, and Review Department

\section{After the Fall: Lessons for Policy Cooperation from the Crisis \\ Prepared by Tamim Bayoumi ${ }^{1}$}

June 2014

\section{This Working Paper should not be reported as representing the views of the IMF.} The views expressed in this Working Paper are those of the author(s) and do not necessarily represent those of the IMF or IMF policy. Working Papers describe research in progress by the author(s) and are published to elicit comments and to further debate.

\begin{abstract}
A crisis is a terrible thing to waste, and nowhere is this truer than in the arena of international economic policy cooperation. With the world facing the largest and most synchronized plunge in output of the postwar era, policy makers banded together to find solutions. This paper looks at the lessons from what did—and did not—occur in the area of policy cooperation since the crisis. Outcomes seem to be weaker over time in areas such as macroeconomic policies, where institutional procedures were less well defined and there were disagreements over spillovers. By contrast, cooperation seems to have been most effective where there was a consensus that such policies could avoid the risk of highly detrimental outcomes and institutional arrangements were more concrete. Principle amongst these was trade, but bank capital buffers, IMF resources, and derivatives exchanges also fall into this category. Lessons for those interested in promoting cooperation seems to be: it may be more fruitful to: focus on the potential for major costs from a lack of cooperation, rather than the minor gains from fuller coordination; strive for more consensus estimated spillovers; convince policy-makers costs of loss of cooperation are large; and focus on building better and more enduring institutional arrangements.
\end{abstract}

JEL Classification Numbers: F42, F35, F33, F13, E61

Keywords: Policy cooperation, institutuinal coarregements; policy spillovers Author's E-Mail Address: tbayoumi@imf.org

\footnotetext{
${ }^{1}$ The views in this paper are my own, and should not be reported as representing the views of the IMF. Contact details: tbayoumi@imf.org. The initial draft was prepared for a Chatham House/IMF Workshop New Directions in Policy Coordination, held in Washington, DC September 122013.
} 


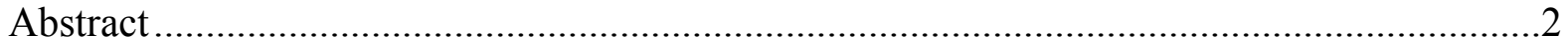

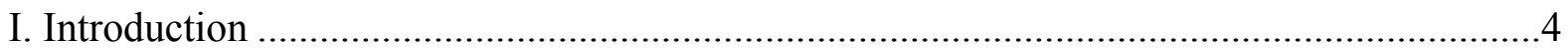

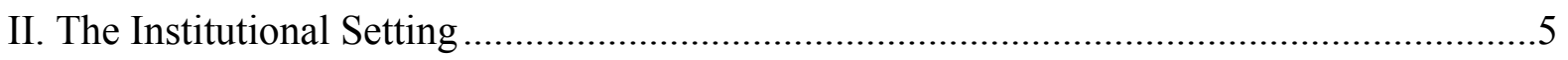

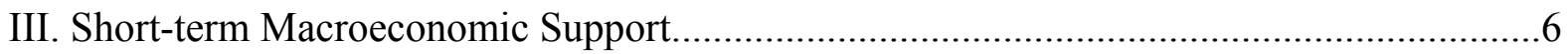

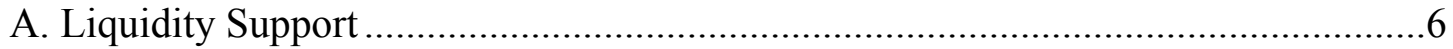

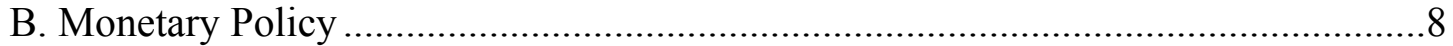

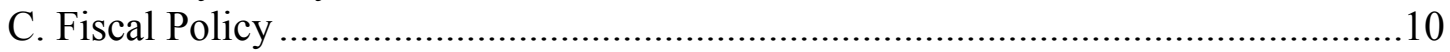

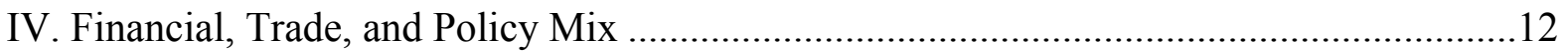

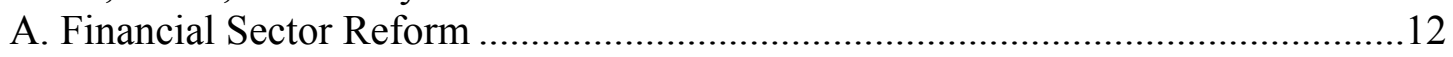

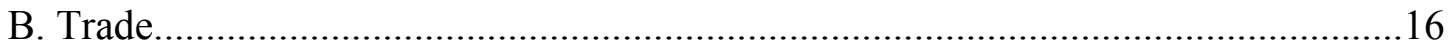

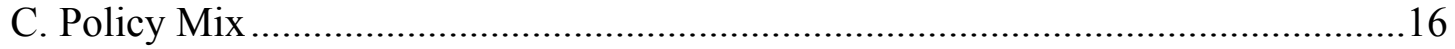

V. Domestic Policy Cooperation ......................................................................................18

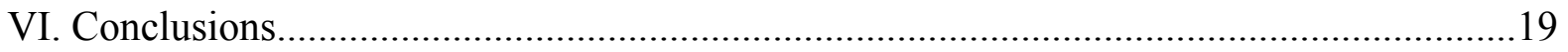

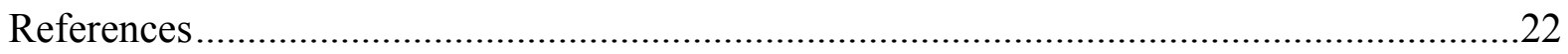




\section{INTRODUCTION}

"A crisis is a terrible thing to waste" is a quip that could be used about many economics papers over the last 5 years, and this one continues in that fine tradition. The particular issue I focus on is what the policy responses since the 2007/08 crisis tell us about policy cooperation in the real world. After all, the Lehman bankruptcy led to the deepest and most synchronized global downturn of the postwar era. With the close linkages and dependencies of one country on another so dramatically exposed, and the risk of a new great depression on the horizon, the impulse for collective action was inevitably heightened. What was done and-possibly equally importantly - what was not done over the subsequent half decade provides a natural experiment to examine the impulses towards policy coordination and its practical limitations.

Accordingly, this paper looks at policy cooperation in the period since the Lehman collapse using an historical approach. More specifically, it discusses what has happened and provides some assessment as to why, supported by references to more detailed analysis. This "revealed preference" and historical approach using observed behavior is used to infer preferences contrasts strongly with the typical approach in the policy coordination literature of developing a model and then assessing appropriate behavior based on welfare maximization. The outcome is some relatively unconventional ideas on how to promote policy cooperation.

The first task is to define policy cooperation. The Oxford English Dictionary defines cooperation as "the process of working together to the same end". This captures the essential point that cooperation implies a willingness of policy makers to take account of spillovers to others when setting policies, which implies the need for active dialogue. It goes less far than policy coordination - the phrase often used in the literature - which is defined as "the organization of the different elements of a complex body or activity so as to enable them to work together effectively" (emphasis added). I adopt the less intrusive word "cooperation" for two reasons. First, as a practical matter, few policy institutions are likely to be willing to accept the external constraints implied in "the organization of the different elements." Second, even if they were willing to do so, such arrangements would likely run afoul of institutional mandates involving fairly narrow goals. That said, it is clear that some of the policies discussed below (such as raising the IMF's lending capacity) would also qualify as policy coordination.

The next section briefly discusses the broad institutional setting. The following one examines the experience with the various individual policy areas discussed in the G-20-liquidity, monetary, fiscal, financial, trade, and the policy mix (the G-20 mutual assessment process, representing the "grand bargain" approach). This is followed by a brief discussion on domestic policy cooperation. In the concluding section, these experiences are bought together to draw lessons about how to successfully enhance policy cooperation in the future. 


\section{The InSTITUTIONAL SETTING}

I start with a discussion of how the crisis changed the institutional environment within which policies were made. Here, there is a clear division between the evolution of macroeconomic and many structural policies (for example, monetary policy, financial regulation, fiscal policy, and structural reforms) and the evolution of areas such as bank capital and trade. In the case of the former, the international environment changed drastically after the crisis, as the center of decision making moved rapidly from smaller groups of high income countries with similar concerns and frameworks (e.g., the G-7 and the Financial Stability Forum) to wider groups encompassing much more diverse approaches and viewpoints (e.g., the G-20 and the Financial Stability Board). While the membership broadened, however, the informal approach of avoiding well defined enforcement procedures and relying largely on consensus remained.

By contrast, in the case of trade and bank capital rules the initial institutions arrangements were much more inclusive. The World Trade Organization and the Basel Committee on Banking Supervision (plus its associated Basel Consultative Group) had a wide and diverse membership from their inception. ${ }^{2}$ The WTO had a more organized coordination procedure through a legal framework, while the Basel committee was limited to providing directives on how policies should be changed. The existence of a wide membership and better organized coordination has an important corollary, in that it signals a much greater international consensus about the value of ensuring consistent and stable trade relations (and, to some extent, bank capital regulations) than is true for (say) macroeconomic policies, which were seen as much more the responsibility of domestic actors. This is a theme that I will return to below.

The sudden rise in prominence of the G20 also provides a useful organizing principle for the rest of this paper. The initial meeting of the G20 leaders in Washington in November 2008 produced a communiqué with an action plan on short-term policy support and on reform of financial markets as well as some discussion of resisting trade and financial protectionism and of achieving stronger growth. Having assessed that "Major underlying factors to the current situation were, amongst others, inconsistent and insufficiently coordinated macroeconomic policies, inadequate structural reforms, which led to unsustainable global macroeconomic outcomes" the leader's communiqué stated that "A broader policy response is needed, based on closer macroeconomic cooperation, to restore growth, avoid negative spillovers and support emerging market economies and developing countries." (emphasis added).

\footnotetext{
${ }^{2}$ While the membership of the Basel committee remains somewhat smaller than the World Trade Organization, this is appropriate as the target audience of countries with internationally active banks, which is smaller than the number of countries involved in international trade.
} 
The agenda was updated and broadened in subsequent leaders summits. ${ }^{3}$ In particular, in the next G-20 leaders' summit in London in April 2009 the trade and growth discussions were deepened under the headings of "Resisting Protectionism and Promoting Global Trade and Investment" and "Ensuring a Fair and Sustainable Recovery for All". With these additions, the action plan covered two broad areas, short-term macroeconomic support (liquidity, monetary, and fiscal policies) and structural reforms (financial sector regulation, trade, and structural policies). These are the areas that I discuss below. Other issues covered in the communiqués but less relevant to this paper, such as climate change, are not covered.

\section{SHORT-TERM MACROECONOMIC SUPPORT}

Post-crisis macro support can be divided into three types: liquidity support to stabilize markets, most notably in the immediate aftermath of the crisis; monetary policies to support demand both conventional (via policy rate cuts) and unconventional (via asset purchases and forward guidance); and fiscal policies. ${ }^{4}$ The outcomes for international policy cooperation were significantly different — notable changes in liquidity management but limited cooperation outside of the immediate crisis for monetary and fiscal policies.

\section{A. Liquidity Support}

For liquidity support, one of the most visible areas of international cooperation was the introduction of reciprocal swap lines across the major central banks (discussed in Fleming and Klagge, 2010). ${ }^{5}$ Swap lines between the Fed and the European Central Bank and the Swiss National Banks were initiated in 12 December 2007, about five months after the August announcement by BNP Paribas about its inability to price some assets that is generally regarded as the opening salvo of the crisis. ${ }^{6}$ The swap lines were created as it became clear that despite Fed domestic liquidity support programs, whose recipients were often European banks with US operations, the breakdown of traditional sources of foreign exchange was leading to a lack of dollar liquidity in European markets. This was both disrupting local markets in Europe and creating strains in US markets when they opened. ${ }^{7}$

Things sped up after the Lehman bankruptcy filing on September 15, 2008 as global markets froze. Just three days later, before the European markets opened (3:00 a.m. EST!) the Fed and other participants announced that these existing lines had been expanded and new swap

\footnotetext{
${ }^{3}$ The full set of communiqués and other useful G-20 information can be found at the University of Toronto's G-20 Information Center at http://www.g20.utoronto.ca.

${ }^{4}$ See IMF (2013a) on the link between short-term liquidity support and other unconventional monetary policies.

${ }^{5}$ See also Board of Governors of the Federal Reserve System (2013a, b).

${ }^{6}$ BNP Paribas announced that it was unable to it was unable to determine net asset values for three of its creditfocused hedge funds and would suspend redemptions from those funds.

${ }^{7}$ Federal Reserve Bank of New York (2013).
} 
lines had been initiated with the Bank of Canada, Bank of England, and Bank of Japan. Six days later (September 24) the Fed program was further extended to include the central banks of Australia, Sweden, Norway, and Denmark, thereby covering most of the advanced world. In mid-October, the caps on the swap arrangements were lifted, allowing unlimited borrowing by four of the five "core" central banks (European Central Bank, Bank of Japan, Bank of England, and Swiss National Bank). In late October, further Fed swap lines were initiated with major Latin American emerging market central banks-Brazil, Mexico-as well as three other Asian advanced markets-Korea, Singapore, and New Zealand.

Given continuing financial market strains these swaps, which were initially supposed to end on April 30, 2009, were extended twice, being eventually terminated on February 1, 2010. On May 9 of that year, continuing financial strains forced the reintroduction of Fed swap lines with the "core" central banks. ${ }^{8}$ After being extended on several occasions, these arrangements were made into standing arrangements that will "remain in place until further notice" as a "prudent liquidity backstop" in October 2013. These permanent swap lines are different from earlier ones which either effectively supplemented international reserves (up to the 1990s) or were very short-term (after the $9 / 11$ terrorist attack). This change in the role of swaps from providing reserves to providing a permanent liquidity backstop presumably reflects the trend from limited capital movements to financial globalization, which has increased the need for liquidity buffers (Rey, 2013).

While the central bank swap lines were in theory reciprocal, involving potential loans from the Fed in dollars and to the Fed in foreign currencies, in practice they provided dollar liquidity. The Fed loaned dollars to most of the other central banks (exceptions were the central banks of Brazil, New Zealand, and Singapore), but never borrowed foreign currency. This reflected the dominant position of dollar markets in the international financial system (IMF, 2011).

In addition to being essentially one-way, the swap lines created some tensions with those not included in the Fed's dollar safety net. As with any club, there was (and still is) a certain amount of dissatisfaction from those who were not included in the swaps as to how the countries that received swaps were chosen. Understandably, given its desire to remain flexible, the Fed did not provide details of how recipients were chosen.

Another example of international cooperation was the expansion of the IMF lending capacity. This lending had previously been shrinking steadily as a ratio of the obvious metrics such as world trade or (in particular) international capital flows. Faced with a global financial shock which required large new Fund programs there was an agreement at the Washington G20 leaders' summit in November 2008 that Fund resources needed to be augmented.

\footnotetext{
${ }^{8}$ See http://www.newyorkfed.org/markets/liquidity_swap.html.
} 
By the April 2009 London summit this had hardened into a goal of tripling Fund lending capacity from $\$ 250 \mathrm{~b}$ to $\$ 750 \mathrm{~b}$. By the Pittsburgh summit in November a permanent increase in Fund lending capacity was achieved through bilateral pledges that were then folded into the (already existing) New Agreement to Borrow, ${ }^{9}$ to be later partially rolled back by the lengthier process of a quota increase that would also add legitimacy to the Fund by realigning outdated voting shares closer to current economic reality. ${ }^{10}$ The failure of the US Congress to pass the US quota increase by early 2014, however, has delayed this process as the required super-majority for the proposed changes in Fund quotas is not available.

On a more temporary basis, as the crisis in Europe worsened in 2011 there was felt to be a need for a further, short-term, increase in Fund lending capacity. In a strong show of solidarity, the Fund obtained additional bilateral pledges of \$461b by the Spring 2012 meeting of the International Monetary and Financial Committees (the Fund's governing body), despite the inability of the US to contribute due to political constraints. While the conditions vary depending on the lender, these pledges generally lasted for 2-4 years. The expansion in available liquidity via swap lines and the expansion of Fund resources are an enduring legacy of cooperation from the crisis.

\section{B. Monetary Policy}

Turning to monetary policies primarily aimed at supporting demand, in the initial stages of the crisis interest rate cuts were primarily in North America. This reflected a belief, incorrect looking back, that the problems were primarily in the United States. This changed after the Lehman bankruptcy and on October 8 - in the middle of the extension of swaps - there was a concerted $1 / 2$ percentage point cut in policy rates by the Fed, ECB, the Bank of England, the Bank of Canada, and Sweden's Riksbank. The Swiss National Bank also lowered its benchmark rate and the Bank of Japan endorsed the move. Even more interestingly, the Peoples Bank of China cut a key interest rate and lowered reserve requirements. ${ }^{11}$

This cooperation, however, soon diminished for a number of reasons. Within a few months, the Fed had cut its policy rate effectively to zero thereby precluding further coordinated rate cuts. Rather, the Fed embarked on unconventional monetary policies initially aimed at unclogging the monetary transmission channel (initial announcements of Fed purchases of MBS occurred in November 2008) then at general macroeconomic support via forward guidance on the path of policy rates (initial announcement in December 2008) and via purchases of Treasury bonds (announced the following March) (see IMF 2013a, b, f).

\footnotetext{
${ }^{9}$ Not all countries that made bilateral pledges were part of the New Agreement to Borrow, and some New Agreement to Borrow countries did not participate in the initial round of bilateral pledges (for more detail see IMF, 2013g).

${ }^{10}$ There were also smaller funds raised in support of trade finance and multilateral development banks.

${ }^{11}$ New York Times, 2008.
} 
Other central banks subsequently also announced unconventional policies. The Bank of England initiating asset purchases in March 2009, the Bank of Japan forward guidance and asset purchases in 2010, and the European Central Bank its Securities Market Program to stabilize financial conditions later in $2010 .^{12}$

The press releases initiating unconventional monetary policies are in all cases focused on domestic conditions (see Federal Reserve Board (2009), European Central Bank (2011), Bank of Japan (2012), and Bank of England (2009)). The Federal Reserve statement had no mention of the rest of the world, while the ECB and Bank of Japan releases discuss prospects for exports but only as part of the assessment of domestic prospects; the Bank of England Minutes discuss the global economy in more detail, and do mention in passing that support from other central banks might support UK exports, but this is the closest any central bank gets to discussing the international impact of policies, and the focus is on the impact of other country policies on the UK. ${ }^{13}$

There is no more evidence of policy cooperation later. For example, three major monetary expansions in the fall and winter of 2012/13 were announced in relatively quick successionthe Open Market Transactions program by the European Central Bank in August/early September, the un-time-bound bond buying operation (QE3) by the Fed in mid-September, and a new 2 percent inflation target by the Bank of Japan in January 2013 shortly after the election of prime minister Abe (who was known to favor a more expansive monetary stance) in December. Yet the associates press releases were also devoid of a global view (European Central Bank, 2012, Federal Reserve Board, 2012, Bank of Japan, 2013).

There is also scant evidence of cooperation with recipient countries until recently. As the initial crisis receded and markets stabilized, unconventional policies appear to have been associated with major capital flows, including into a number of emerging markets (IMF, 2013f, and g). Indeed, in 2012 and early 2013 several emerging markets complained of a wall of money coming in that had appreciated their exchange rates and that might reverse rapidly, but these concerns elicited no response from source country central banks. ${ }^{14} \mathrm{~A}$ reversal in emerging market inflows and rise in market volatility does indeed seem to have started after the May 22, 2013 discussion of tapering of Fed purchases by Chairman Bernanke.

\footnotetext{
${ }^{12}$ There was also a gap between the approach of the European Central Bank, which interpreted its mandate as only allowing support for the financial sector and was in any case more concerned about the moral hazard its actions could cause by lowering the incentives for governments to solve underlying financial strains, and the other major central banks that pursued a more eclectic set of policies that focused on supporting domestic activity as well as financial stability.

${ }^{13}$ The statements are readily available on the respective central bank web sites. See, for example, Federal Reserve (2009), Bank of England (2009), European Central Bank (2011), and Bank of Japan (2012).

${ }^{14}$ See, for example, Reuters (2013).
} 
More recently, the tension around monetary policy spillovers and interconnectedness appears to have been lowered somewhat after the September 5-6, 2013 G-20 leaders St. Petersburg summit. The communiqué recognized both spillovers from source countries ("We remain mindful of the risks and unintended side effects of extended periods of monetary easing." and "Our central banks have committed that future changes to monetary policy settings will continue to be carefully calibrated and clearly communicated") and the need for recipient countries to pursue better domestic policies ("Generally stronger policy frameworks in these countries allow them to better deal with these challenges"). The communiqué after the February 22-23 Meeting of Finance Ministers and Central Bank Governors in Sydney stated "As markets react to various policy transitions and country circumstances, asset prices and exchange rates adjust.... We will consistently communicate our actions to each other and to the public, and continue to cooperate on managing spillovers to other countries, and to ensure the continued effectiveness of global safety nets." (emphasis added).

\section{Fiscal Policy}

The history of global fiscal policy cooperation after the crisis is a good example of how impressive initial cooperation diffused over time. In this case, the natural tendency to reduce cooperation after the immediate crisis passed was compounded by disagreements on the relative importance of the benefits of expansionary fiscal policy via Keynesian demand support versus the losses from non-Keynesian effects on confidence from a higher projected level of future debt. There was also a division between those who focused on the need for short-term demand stimulus and those who were more concerned about moral hazard leading to laxer future policies.

As with monetary policy, policy cooperation occurred almost immediately after the Lehman bankruptcy. The G-20 leaders' summit on November 15, 2008 in Washington generated a wide ranging statement on the causes and responses to the crisis which included a vague statement on the need to "...use fiscal measures to stimulate demand to rapid effect, as appropriate, while maintaining a policy framework conducive to fiscal sustainability." This careful phrasing managed to balance the support for fiscal expansion to support growth with the concerns about the impact of such expansions on fiscal sustainability.

That day, however, the Managing Director of the IMF was much more concrete during press conference. Mr. Strauss Kahn argued that the fiscal multiplier was around one, that coordinated expansion would minimize leakage to other countries, that monetary room was limited, and that risks to inflation were minimal and said "What we're trying to organize is this coordinated action plan to have a boost in growth starting from a [global] fiscal stimulus of 2 percent [of world GDP]. Some measures have already been taken by some countries, and we are looking for a result of an increase in growth of also 2 percent." 15

\footnotetext{
${ }^{15} \mathrm{http}: / / w w w . i m f . o r g / e x t e r n a l / n p / t r / 2008 / \operatorname{tr} 081115 . \mathrm{htm}$.
} 
The call for a stimulus of 2 percent of GDP rapidly became a rallying cry that generated an impressive and coordinated fiscal shot in the arm. Fund analysis at the time suggests that stimulus measures were pledged with real water of the order of 11/4-2 percent of (weighted) G20 GDP in 2009 and 1 1/2 percent of GDP in 2010 (Horton, Kumar, and Mauro, 2009, IMF, $2009 \mathrm{a}, \mathrm{b})$. It is notable that the largest stimulus occurred in the large economies, where leakage to the rest of the world was smallest. The three largest stimulus packages involved three of the four largest G-20 economies - the United States promised stimulus of 2 and 3 percent of GDP in 2009 and 2010, respectively, China 2 percent in both years, and Germany (despite its reputation for fiscal probity) $1 \frac{1}{2}$ and 2 percent. Even Japan, wearied by a lost decade featuring numerous fiscal stimulus packages, announced fiscal stimulus amounting to almost 2 percent of GDP over the two years.

The outcome seems to have been similar to the plans, with the world getting a major fiscal boost in 2009 that was largely maintained in 2010 . G-20 advanced economies are estimated to have boosted their cyclically adjusted deficits by $2 \frac{1}{2}$ percent of GDP in 2009 and a further $1 / 2$ percent in 2010, while their emerging market brethren provided stimulus of $2 \frac{1}{4}$ percent of GDP in 2009 before withdrawing almost a percentage point in 2010 as Chinese stimulus was withdrawn early given the rapid rebound of growth. ${ }^{16}$

Almost two years later, against the background of an expected global recovery, the G-20 leaders pledged to also coordinate the subsequent reduction in fiscal deficits at the Toronto summit in June 2010. After first noting the dilemma that "The path of [fiscal] adjustment must be carefully calibrated to sustain the recovery in private demand. There is a risk that synchronized fiscal adjustment across several major economies could adversely impact the recovery. There is also a risk that failure to implement consolidation where necessary would undermine confidence and hamper growth." the leaders of advanced economies committed to "fiscal plans that will at least halve budget deficits by 2013 and stabilize or reduce government debt-to-GDP rations by 2016." With a global recovery expected and bank support winding down, this commitment seemed easily within reach.

However, with growth remaining sluggish as the European crisis took hold these plans became more challenging. There was a very real danger that the 2013 goal could be missed by several countries, including the United States and Japan. ${ }^{17}$ Behind this was a wider intellectual break between governments (prominently the United States) who tended to emphasize the short-term benefits of Keynesian demand stimulus and those (prominently Germany) who were concerned about the impact of higher debt on long-term growth and short-term private sector confidence (Official Monetary and Financial Institutions Forum, 2012, and Financial Times, 2013a). This difference in view eroded impetus for further fiscal

\footnotetext{
${ }^{16}$ See IMF (2013e). Note, however, that these data include some factors not included in the earlier calculations, such as financial sector support, and are hence do not correspond exactly with plans for stimulus.

${ }^{17}$ The outturn seems likely to be that the United States achieved its 2013 target but Japan missed its one.
} 
cooperation or using faster/slower consolidation to rebalance global demand between deficit and surplus countries through the G20 process. This is clearly seen in the subsequent leaders' communiqués, which limited themselves to general statements such as the need for "fiscal consolidation where necessary" (November 2011, Seoul leader's summit communiqué).

Fiscal policy was also a focus in Europe, combining somewhat divisive discussions of shortterm policy with more progress on longer-term reforms. The Stability and Growth Pact implied the need to lower the nominal fiscal deficit below 3 percent of GDP within a short space of time. As the European crisis intensified and the Euro area moved into recession, the gap widened between governments that saw achieving difficult nominal fiscal deficits as largely self-defeating through its impact on growth and investor confidence, and governments that believed that deviations from this path would further exacerbate financial tremors about debt sustainability (Financial Times, 2013b and c). More generally, external surplus countries were unwilling to consolidate slowly to rebalance demand away from the periphery that was being forced by market forces to consolidate rapidly. As with the G-20 process, this eroded the basis for short-term fiscal cooperation across the members of the currency bloc. The final outcome has been a process that provides significant leeway for countries to determine their own fiscal paths, a bit like the G-20 result.

By contrast, there was more progress on the structure of fiscal surveillance in Europe. The fiscal problems in the periphery (most notably Greece) laid bare over the global crisis made clear that the existing fiscal rule outlined in the Stability and Growth Pact arrangements needed to be strengthened. The result was a series of reforms, including the Fiscal Compact, Six Pack, and Two Pack. The effectiveness of these changes in structure will only become apparent over time (see European Commission, 2013, for a description).

\section{Financial, Trade, And Policy Mix}

\section{A. Financial Sector Reform}

The majority of the first G20 leaders' summit communiqué held in Washington in 2008 was devoted to defining an action plan to reform financial markets, reflecting the centrality of financial market dysfunction to the crisis. ${ }^{18}$ Noting that "our financial markets are global in scope" the leaders stated that "intensified international cooperation among regulators and strengthening of international standards, where necessary, and their consistent implementation is necessary to protect against adverse cross-border, regional and global developments affecting international financial stability" (emphasis added). The agenda involved separate work streams strengthening transparency and accountability, enhancing sound regulation, promoting integrity of financial markets, reinforcing international

\footnotetext{
${ }^{18}$ This section focuses on regulatory reform. Support for banks was vigorous initially in the face of the crisis, but less thorough in terms of its approach to cleaning up banks (Claessens and others, forthcoming).
} 
cooperation, and reforming the international financial institutions - in this context meaning broadening the membership of the Financial Stability Forum to emerging markets.

Compared to the rest of the document, the financial action plan involved a more detailed set of objectives. These included initiatives to clear up weaknesses brought out by the crisis, such as: tighter regulation of credit rating agencies; expansion of the membership of the Financial Stability Forum; better risk modeling by banks; making World Bank/Fund Financial Sector Assessment Programs mandatory for major economies; and greater disclosure of complex financial instruments, financial losses, and off-balance sheet structured investment vehicles. While these initiatives were important, they were also relatively easy to agree on - the financial sector equivalent of the initial fiscal stimulus in the face of global output risks.

The communiqué also included a number of "wish list" improvements which subsequently largely fell by the wayside for various reasons. Examples include: the unification of global accounting practices (an objective even before the crisis); a desire to regulate or oversee all financial institutions, products, and markets (while hedge funds are now registered, a regime covering all financial firms, products, and markets appears impractical); and bringing greater unity to the regulation of banking, insurance, and other sectors (different business models imply different regulatory concerns).

The main issues in the action plan involved cooperative approaches to strengthening the capital adequacy regime including making it less pro-cyclical and raising ratios for systemic institutions to offset the funding advantages from being "too big to fail", to improving crisis management and response tools such as resolution and bankruptcy, to minimizing the impact of non-compliant countries on secrecy and soundness, to avoiding perverse incentives from compensation packages, and to increasing the transparency and safety of derivatives trading by moving to centralized exchanges.

The basic story in all of these areas involves the creation of sound plans for reform accompanied by somewhat uneven implementation. ${ }^{19}$ Take capital regulation as an example. The crisis exposed the flaws in the existing "Basel 2" international capital standards that mandated banks to hold capital worth 8 percent of their risk-weighted assets. While these standards were supposed to ensure adequate buffers to avoid banking crises, they suffered from three flaws.

- $\quad$ Capital dilution. The minutely negotiated definition of capital included many provisions that catered to the particular structures of country banking systems, diluting the loss-absorbing character of the capital.

\footnotetext{
${ }^{19}$ See Financial Stability Board (2013a, b) for an update on progress in the main G-20 objectives.
} 
- $\quad$ Risk dilution. Larger advance economy banks, in particular universal banks in Europe, were allowed wide latitude to use their internal models to assess the riskiness of products. They used this freedom to minimize their risk-weighted assets and hence expand their balance sheets.

- $\quad$ Fragmentation. While the rest of the world focused solely on risk-weighted assets, the US bank regulators never implemented Basel 2. The US commercial banks had a "simple leverage ratio" where capital had to be held as a ratio to total, as opposed to risk weighted, assets. The advantage of a simple leverage ratio is it is more difficult to manipulate. The disadvantage is that the US commercial banks were under a different regulatory system than the rest of the advanced economies that rewarded an originate to distribute model for "safe" assets such as mortgages. Meanwhile, the US investment banks and government sponsored enterprises - major parts of the US financial system - were under a different capital regime that had similar flaws to those in the rest of the world.

The outcome was a system in which US commercial banks had an incentive to move assets off balance sheet to preserve capital even as European banks were looking to buy assets (Bayoumi and Bui 2012, Bayoumi and Ismael 2013). This led to the transfer of US housing loans from the relatively well capitalized US commercial banks to the lightly capitalized US investment and European universal banks (and the US government sponsored enterprises). This explains why a US housing problem produced a major hit on the US investment banks and European banks but was a somewhat smaller problem for the US commercial banks that often originated the loans.

The new Basel 2.5 and Basel 3 proposals (Basel Committee, 2011 and 2013) are undoubtedly a major improvement over the Basel 2 system. They include a tighter definition of capital, proposals to augment the risk-weighted ratio with a simple leverage ratio, a liquidity coverage ratio to help ensure a bank can continue to function even with financial market turmoil, and capital surcharges to large banks to offset the funding advantage from being "too big to fail."

Good progress has been made on identifying systemic financial institutions and adding higher capital requirements. But in the pained negotiations, the core standards have often been watered down (e.g., the liquidity ratio was made weaker), only partly implemented (proposed EU capital definitions appear inconsistent with the principles), delayed (Basel 3 will not go into effect until 2018), and/or ignored (the EU is still umming and erring on whether to implement the simple leverage ratio). In addition, little has been done about the pro-cyclicality of capital. Furthermore, countries have tended to lead the regulators with their own separate proposals (Dodd-Frank in the US, Vickers in the UK, Liikanen in the EU). AT least one knowledgeable commentator sees the risk "we end up with "pickandchoose.com" and a "real danger that significant systemic regulatory fragmentation will emerge" (Wright, 2014). 
To underline this point, perhaps even more surprising than the inevitable compromises involved in negotiations involving complex and different banking systems is the fact that in some respects the evolving system looks relatively similar to the one that it replaced. The main focus remains on risk weighted capital assessed with the assistance of banks' internal risk models (albeit with better safeguards). The new concept of a liquidity coverage ratio risks is being diluted, arguably to a point where its impact could be relatively muted. Finally, the US regulators plan to impose a simple leverage ratio of 6 percent on their major commercial banks (in a major change, commercial banks now include the surviving major investment banks both domestic — such as Goldman Sachs and Morgan Stanley - and foreign — such as Deutsche Bank and Barclays Capital). Since this simple leverage ratio may well be the binding capital constraint on most major US banks, it seems very possible that the US-based banks would again in practice face a different type of capital regime than similar banks elsewhere (quite apart from continuing differences in accounting standards that muddy the comparison of capital standards between the US and other countries).

The underlying story with regard to crisis management and resolution is similar. Clear progress on principals combined with some dissonance across countries. "Key Attributes of Effective Resolution Regimes" 20 provides a useful blueprint for a unified global approach to this issue, but implementation is slow and different across jurisdictions, with the United States in particular taking a quite parochial view on some matters. In addition, cross-border resolution - with its tricky burden sharing issues - has tended to lag, although recent proposals for a "Single Point of Entry" approach to cross-border resolution between the US and UK and Switzerland could be expanded and holds promise for the future.

In a similar story, useful principles have been created for non-compliant countries and for compensation. In the case of non-compliant countries, compliance is (maybe predictably) difficult to ascertain. One area where significant progress has been made is banking secrecy, particularly with respect to jurisdictions such as Switzerland. On compensation, the indifference of the United States to this issue has meant that despite some individual efforts - most notably in France, but also the United Kingdom - the overall outcome has been limited.

Finally, the move to derivatives trading on exchanges has been slower than anticipated as some earlier concerns about financial protectionism were resolved. Meanwhile, more derivatives than ever are being traded over the counter. In addition, the agenda to move to exchanges themselves have some very real issues. For example, this risks creating new institutions that are too big to fail and potentially have inadequate risk management standards, contingency planning, and resolution tools.

\footnotetext{
${ }^{20}$ Financial Stability Board (2011).
} 


\section{B. Trade}

The November 2008 leaders' summit communiqué mentioned the need to resist protectionism and trade and investment only in passing. In the April 2009 London Summit declaration, however, the leaders committed to "refrain from raising new barriers to investment or trade in goods and services, imposing new export restrictions, or implementing World Trade Organization (WTO) inconsistent measures to stimulate exports" until the end of 2010. In response to concerns that trade might be being constrained by a lack of finance and new capital charges, $\$ 250 \mathrm{~b}$ in additional trade credit was pledged and regulators were asked to use "available flexibility" in capital requirements for trade finance.

With slow growth continuing and concerns about trade finance moving to the back burner, subsequent communiqués announced steady extensions of the pledge against protectionism. The current end date is end-2016. Furthermore, while there were some move to protectionism most notably by some emerging markets and some well publicized incidents (US curbs on Chinese tire imports, China restrictions on export of rare metals) the pledge has basically worked. Restrictions still cover less that 4 percent of G-20 imports, while econometric models would have predicted a much larger jump (Brown and Crowley, 2012). ${ }^{21}$ Although some of this might reflect the "padding" created by the gap between actual and bound tariffs, the story of significant restraint compared to fears seems to hold.

The combination of generalized concern over the destructive nature of trade wars and a strong legal process appears to have kept the open trade regime relatively intact. The collective memory of the harm wrought by protectionism in the 1930s may have weighed on policymakers. But the strong institutional arrangements associated with the World Trade Organization may well also have played a part. The highly structured and transparent framework for trade disputes, involving legal cases, panel decisions, and countervailing duties may well have deterred any large-scale shift to protectionism.

\section{Policy Mix}

The communiqués from the first two leaders' summits focused in short-term macroeconomic policies and financial repair. The one from the Pittsburgh summit in September 2009, however, announced a new initiative "a framework that lays out the policies and the way we act together to generate strong, sustainable and balanced global growth" (italics in the original). To achieve that plan "Our Framework for Strong, Sustainable and Balanced Growth is a compact that commits us to work together to assess how our policies fit together,

\footnotetext{
${ }^{21}$ The paper finds that for the advanced countries that they study import protection was only one-fifteenth of what their model would predict. Supportive of the role of cooperation, the paper also finds that the largest change in behavior was in refraining from adding protectionist measures on countries whose growth was slowing. While other factors, such as the rise of global supply chains may have played a role, the effect seems too large to be dismissed.
} 
to evaluate whether they are collectively consistent with more sustainable and balanced growth, and to act as necessary to meet out common objectives."

The objective of this process was to "all work together to ensure that our fiscal, monetary, trade, and structural policies are collectively consistent with more sustainable and balanced trajectories for growth." The project was to be support by "candid, even-handed, and balanced analysis of our policies" provided by the Fund and other international organizations. The G20 Mutual Assessment Process (MAP for short) was thus an ambitious plan to create policy cooperation at the highest level.

As seen by Fund staff, the MAP process could overcome two distinct policy cooperation failures (Faruqee and Srinivasan, 2012). The first cooperation failure was ensuring that strategic interactions across countries were properly internalized. Their example was that lowering global imbalances without compromising global growth required that a reduction in domestic demand relative to output in deficit countries - such as the United States - was offset by an increase in domestic demand relative to output in the surplus countries - such as China. If the US went it alone, the outcome would be lower imbalances but also lower global growth if the Chinese tried to preserve domestic growth by devaluing to boost external demand. The second cooperation failure was that peer pressure could erode political obstacles to beneficial policies in an interconnected world.

While the G-20 turned out to be a good fire fighter, as conditions normalized the outcome was rather more deflating than the high ideals laid forth by the leaders (Angeloni and PisaniFerry, 2011). The political will essential to the process was gradually eroded by:

- $\quad$ Splintered objectives. Bureaucrats could not agree on whether strong, sustainable, and balanced growth represented a single goal or three objectives. They eventually plumped for three, leading to a widening of policy commitments in the Toronto and Seoul summits that lessened accountability. This was exacerbated by differing country circumstances that led to divergences in views on the urgency of policy action and responsibilities to the global economy.

- $\quad$ Distrust. Partly in response of the splintering of objectives, at the Seoul summit in November 2010 the MAP became focused on external imbalances and identifying countries that had internal imbalances that contributed to these external ones. This raised suspicions about the true intent of the exercise for many emerging markets. Disagreements about the value of unconventional monetary policies, discussed earlier, further widened the gap between advanced economies and emerging markets.

- Distractions. The reintensification of the crisis in Europe distracted policy makers from medium-term structural solutions to imbalances to more immediate fire fighting focused on one particular area of the G20. Also, given the problems largely reflected 
intra-euro area issues, non-European views on policies and their cooperation were neither welcomed nor acted upon.

Over time the outcome was a process where countries generally submitted policies that they already planned to do, and where genuine cooperation was minimal. Indeed, the Saint Petersburg summit communiqué in September 2013 had little new in it.

An irony of this outcome is that despite the disappointments of the MAP, global imbalances themselves fell dramatically against a backdrop of rapid growth in emerging markets and continuing stagnation in advanced economies. However, the assessment of the Fund in its 2013 Pilot External Sector Report was that little of the fall had to do with policies, let alone policy cooperation (IMF 2013e). This may be changing as China moves ahead with rebalancing demand in its latest five year plan and US fiscal consolidation occurs under sequestration. However, these initiatives appear to reflect independent national decisions rather than policy cooperation.

Another initiative set up as a result of the initial G-20 leaders summit was that the "The IMF, in collaboration with the expanded FSB and other bodies, should work to better identify vulnerabilities, anticipate potential stresses, and act swiftly to play a key role in crisis response." This became the IMF-FSB early warning exercise (see IMF 2010 for a description). While generally seen as an addition to surveillance rather than policy cooperation, I will argue below than this was indeed important in the latter arena.

\section{Domestic Policy CoOperation}

The focus of this paper thus far has been on international policy cooperation, but an equally important issue is domestic policy cooperation. Indeed, the two are closely linked as domestic monetary and fiscal policies have very different implications for the rest of the world whether in a standard Mundell-Fleming model or in a world with more subtle financial market links (Bayoumi and Vitek, 2013).

The most interesting observation about domestic cooperation of monetary and fiscal policies is how little occurs and how little it was changed by the experience of the crisis. To be fair, there was some notable coordination of fiscal and monetary policy over the crisis (e.g., the bailout of AIG in the United States). However, the basic structures seem to have remained relatively unchanged.

The most important change in domestic macroeconomic institutional arrangements in the decades leading up to the crisis was the move to independent central banks. By 2008 these were ubiquitous in the advanced economies (with the attendant complications caused by the fact that the euro area comprised many sovereigns) and typical in larger emerging markets. The move to independent central banks is generally seen as a great success that has helped lower inflation and improved monetary discipline. But it may have also distracted attention from the domestic policy mix. 
Central banks have typically tended to shy away from discussing the appropriate mix between monetary and fiscal or structural policies in public. Although there may be more discussed behind closed doors, it is not clear that these are highly structured. There are some economic arguments for avoiding cooperation, in that monetary policy is a more flexible instrument than fiscal policy and hence central banks could view moves toward cooperation as an attempt to control their policy decisions. But it seems likely that central banks are also sensitive to risks of political interference.

That being said, given the size of potential spillovers both domestically and internationally from different policy mixes, it seems obvious that some form of policy cooperation is warranted. It seems fairly odd to argue that the United States and China should cooperate to achieve a better global outcome but that the US Fed and Executive Branch should not. After all, economic interconnectedness and spillovers are much larger and clearer within a country than across borders. In addition, fears to political interference should diminish over time as the independence of the central bank becomes accepted as the norm, and in cases where the central bank can discuss fiscal policy with an independent fiscal agency (such as the Congressional Budget Office in the United States) rather than the fiscal authority directly. In short, central bank independence is not the same as policy separation, and should not be seen as such.

Interestingly, the evolving regulatory framework for financial policies has generated a very different outcome in the domestic regulatory sphere. When it became clear that several agencies had responsibilities for different parts of financial regulation the solution has typically been to appoint a high level coordinating group. Why not create a high level committee, ideally comprising independent agencies, that meets regularly to look at the overall macroeconomic and structural policy mix in the short- and medium-term? Such a committee would provide some anchoring for policies while (hopefully) avoiding confidence-sapping public spats about policy decisions.

\section{Conclusions}

This analysis suggests three conclusions that question much of the way that economists have approached policy cooperation. The first is that policy cooperation is normally driven by fears about bad outcomes, not desires for better ones. While economists use modelsestimated and stylized - to eek out gains to welfare from optimizing policies away from the Nash equilibrium, policy makers seem much more motivated by fear than greed. ${ }^{22}$ This is most clear in the fact that cooperation peaks around crises, when the downside outcomes are most obvious. However, this does not mean that we should be looking to have continuous crises to increase cooperation!

\footnotetext{
${ }^{22}$ This is a key concept of prospect theory, a branch of behavioral economics. See Kahneman (2003) for an overview.
} 
The more interesting point is that cooperation seems to be at its most effective in areas where there is general agreement that lack of cooperation will be destructive. The most obvious example is trade, where the memories of the great depression seem to have sensitized all to the risks of a trade war. The reach of the Kindleberger diagram is long. It is particularly striking that concerns about a trade war seem to be have been even larger than concerns about effective financial regulation, even though most economists would probably think of the losses from financial crises as potentially larger than a (less than all out) trade war. Finally, the lack of interest in domestic policy cooperation could reflect the lack of belief that such policies risk major economic losses.

The more general issue is that the potential costs of uncooperative policies can easily spin out of control. Policy makers intrinsically understand the maxim that trust is difficult to win and easy to lose. The risk from blatantly beggar-thy-neighbor policies is that it provides a negative response that ricochets around the globe - a risk that does not exist to anything like the same extent about increases in policy cooperation. Take the case of global rebalancing discussed above. The concern is that if the US lowers domestic demand by cutting its fiscal deficit and China responds by devaluing to preserve domestic growth further exacerbating the slowdown in the US, this will provoke trade and financial retaliation that could rapidly mushroom. This kind of "connecting the dots" to see how negative events could cascade was one motivation for the creation of the IMF/FSB Early Warning Exercise.

The second conclusion is that cooperation is like more effective when the institutional framework exists to provide either enforcement or a well-defined process to achieve goals. Trade is again a good example of enforcement. The existence of the WTO provided a strong framework within which countries could pledge to avoid non-WTO-compatible actions. By contrast, lacking an enforcement mechanism and with fuzzy goals, the "grand bargain" approach of the G-20 MAP rapidly lost momentum. The EU Stability and Growth Pact is an intermediate case where sanctions exist but are unlikely to be used.

Turning to processes to achieve goals, the existence of the IMF was surely crucial to boosting liquidity defenses just as the existence of the Basel committee helped propel the more concrete capital requirement proposals compared to the general principals generated by the Financial Stability Board in other financial areas with its spotty take-up.

A third conclusion is the disagreements caused by striking differences in views across countries on the spillovers of fairly standard policies hurt the impetus for cooperation. The profound Keynesian/non-Keyensian disagreement across major countries over the impact of fiscal consolidation is a case in point. Another is the disagreement about the risks from unconventional monetary policies. Academic models of policy cooperation tend to start from the assumption that policy makers agree on the impact of policies, when often even the sign of the effect may be disputed. Small wonder that grand bargains within and across such policies do not make much headway. 
All of this suggests a three-fold agenda for economists interested in promoting more effective policy cooperation.

- $\quad$ Focus on the potential costs from bad policies rather than the gains from good ones. ${ }^{23}$ Explain why (say) bad financial regulation that creates a crisis can affect others. Even more importantly, explain why and how non-cooperative policies can create a cascade that leads to very bad global outcomes that need to be avoided. In short, connecting the dots is more important than complex modeling of a single dot.

- $\quad$ Put more effort into suggesting better institutional arrangements. Cooperation is much more likely if the associated processes are either enforceable or clear. For Marshall McLuhen the medium was the message. For those interested in policy cooperation, institutions may be at least a large part of the message. As discussed earlier, one example would be to create high level committees to coordinate domestic macroeconomic and structural policies. Another could be to play regular war games on insolvencies of major international banks involving Treasuries not simply regulators.

- Work to get a consensus on the impact of policies both within and across countries. It is striking that in the middle of the crisis there could be such profound differences of view on the impact of fiscal policies at home and abroad and on the international spillovers of (unconventional) monetary policies despite the fact that the monetary transmission mechanism is one of the most studied relationships in macroeconomics. This contrasts with the consensus of the high costs of a trade war. Getting such a consensus will require further work on the nature of international interconnectedness, including the relative role of trade and financial variables in transmitting shocks (IMF, 2012). More generally, economists will need to convince policy makers that the costs emanating from a failure of cooperation are indeed large. Most noneconomists believe that cost of a trade war is large. It is not clear that this is true in other policy areas.

Raymond Chandler memorably wrote about his hardboiled murder mysteries that they got murder from "the vicar's rose garden and back to the people who are really good at it." It is high time for work on policy cooperation to leave the rose garden of linear academic game theory and focus on the underlying concerns of the people who are worry more about really bad outcomes than marginally better ones. I hope this paper can help this process.

\footnotetext{
${ }^{23}$ Benes and others (2013) is an example of such an approach
} 


\section{References}

Angeloni, Ignazio and Jean Pisani-Ferry, 2012, "The G20: Characters in Search of an Author,” Bruegel Working Paper 2012/4 (Brussels: Bruegel Institute).

Bank of England, 2009, "Minutes of the Monetary Policy Meeting March 4-5 2009." http://www.bankofengland.co.uk/publications/minutes/Documents/mpc/pdf/2009/mp c0903.pdf, March 18.

Bank of Japan, 2012, "Statement of Monetary Policy," http://www.boj.or.jp/en/announcements/release_2012/k120313a.pdf, March 13.

_ 2013, "The "Price Stability Target" under the Framework for the Conduct of Monetary Policy," http://www.boj.or.jp/en/announcements/release 2013/k130122b.pdf, January 22.

Basel Committee on Banking Supervision, 2011, "Basel III: A Global Regulatory Framework for more Resilient Banks and Banking Systems," (Bank for International Settlements), revised June 2011.

__ 2013, "Basel III: The Liquidity Coverage Ratio and Liquidity Risk Monitoring Tools," (Bank for International Settlements), January 2011.

Bayoumi, Tamim, and Trung Bui, 2012, “Apocalypse Then: The Evolution of the North Atlantic Economy and the Global Crisis" in The Australian Economy in the 2000s, proceedings of a conference held in Sydney on 15-16 August 2011, Reserve Bank of Australia, p. 37-72.

_ Monetary Fund). Unpublished mimeo.

_ , and Francis Vitek, 2013, "Macroeconomic Model Spillovers and Their Discontents," IMF Working Paper 13/4 (Washington: International Monetary Fund).

Benes, Jaromir, Michael Kumhof, Douglas Laxton, Dirk Muir and Susanna Mursula, 2013, "The Benefits of International Policy Coordination Revisited," IMF Working Paper 13/262 (Washington: International Monetary Fund).

Board of Governors of the Federal Reserve System, 2013a, "Central Bank Liquidity Swap Lines" http://www.federalreserve.gov/newsevents/reform_swaplines.htm.

_ 2013b, "Central Bank Liquidity Swaps," http://www.federalreserve.gov/monetarypolicy/bst liquidityswaps.htm.

Brown, Chad and Meredith Crowley, 2012, "Import Protection, Business Cycles, and Exchange Rates: Evidence from the Great Recession," Journal of International Economics, Volume 90, pp. 50-64. 
Claessens, Stijn, Ceyla Pazarbasioglu, Luc Laeven, Marc Dobler, Fabian Valencia, Oana Nedelescu, and Katherine Seal, 2011, "Crisis management and Resolution: Early Lessons from the 2007-2009 Crisis," IMF Staff Discussion Note No. 11/05 (Washington: International Monetary Fund). https://www.imf.org/external/pubs/cat/longres.aspx?sk=24694.0 ]

European Commission, 2013, "Report on Public Finances in EMU, 2013," European Economy 2013/4.

European Central Bank, 2011, "Introductory Statement to the Press Conference (with Q\&A)," http://www.ecb.europa.eu/press/pressconf/2011/html/is111006.en.html, October 6.

— 2012, "Introductory Statement to the Press Conference (with Q\&A)" http://www.ecb.europa.eu/press/pressconf/2012/html/is120802.en.html, August 2.

Faruqee, Hamid and Krishna Srinivasan, 2013, "The G-20 Mutual Assessment Process-a Perspective from IMF Staff," Oxford Review of Economic Policy, Vol. 28, Number 3, September 26, 2013, pp. 493-511(19).

Federal Reserve Board, 2009, "Press Statement after the March 17-18 FOMC Meeting," http://www.federalreserve.gov/newsevents/press/monetary/20090318a.htm, March 18.

— 2012, "Press Statement after the September 12-13 FOMC Meeting," http://www.federalreserve.gov/newsevents/press/monetary/20120913a.htm, March 18

- 2013, "Transcript of Chairman Bernanke's Press Conference," http://www.federalreserve.gov/mediacenter/files/FOMCpresconf20130918.pdf, September 18.

Federal Reserve Bank of New York, 2013, "Central Bank Liquidity Swaps," http://www.newyorkfed.org/markets/liquidity_swap.html.

Financial Stability Board, 2011, Key Attributes of Effective Resolution Regimes for Financial Institutions, http://www.financialstabilityboard.org/publications/r 111104cc.pdf, October 2011.

_ 2013a, "A Narrative Progress Report on Financial Reforms," Report of the Financial Stability Board to G20 Leaders, September 2013.

— 2013b, "Progress in Implementing the G20 Recommendations on Financial Regulatory Reform," Status report by the FSB Secretariat, September 2013.

Financial Times, 2013a, "Germany Feels US Ire Over War on Currencies," http://www.ft.com/intl/cms/s/0/2d2965f4-4313-11e3-9d3c-00144feabdc0.html, November 1. 
— , 2013b, "Merkel Pressed to Ease up on Austerity," http://www.ft.com/intl/cms/s/0/cf7536d6-acef-11e2-945400144feabdc0.html\#axzz2n0OgM185, April 24.

_ 2013c, "Merkel Speech Highlights European Divide," http://www.ft.com/intl/cms/s/0/665e1018-adae-11e2-a2c700144feabdc0.html\#axzz2n0OgM185, April 25.

Fleming, Michael J. and Nicholas J. Klagge, 2010, “The Federal Reserve's Foreign Exchange Swap Lines" in Current Issues in Economics and Finance, Volume 16, Number 4, April 2010, (New York: Federal Reserve Bank of New York).

Horton, Mark, Manmohan Kumar, and Paolo Mauro, 2009, "The State of Public Finances: A Cross-Country Monitor," IMF Staff Position Note 09/21, (Washington: International Monetary Fund).

International Monetary Fund, 2009a, "The State of Public Finances-Outlook and MediumTerm Policies After the 2008 Crisis," IMF Policy Paper (Washington). http://www.imf.org/external/np/pp/eng/2009/030609.pdf

— 2009b, "Companion Paper: The State of Public Finances-Outlook and MediumTerm Policies After the 2008 Crisis," IMF Policy Paper (Washington). http://www.imf.org/external/np/pp/eng/2009/030609a.pdf

—_, 2010, "The IMF-FSB Early Warning Exercise: Design and Methodological Tool Kit," IMF Policy Paper (Washington). http://www.imf.org/external/np/pp/eng/2010/090110.pdf

—_ 2011, The United States: Spillover Report-2011 Article IV Consultation, IMF Country Report No. 11/203 (Washington).

—_, 2012a, “2012 Spillover Report,” IMF Policy Paper (Washington). http://www.imf.org/external/np/pp/eng/2012/070912.pdf

_ _ 2012b, "The Key Attributes of Effective Resolution Regimes for Financial Institutions - Progress to Date and Next Steps, " IMF Policy Paper (Washington). http://www.imf.org/external/np/pp/eng/2012/082712.pdf

_ , 2013a, "Unconventional Monetary Policy—Recent Experience and Prospects," IMF Policy Paper (Washington). http://www.imf.org/external/np/pp/eng/2013/041813a.pdf

—_, 2013b, "Unconventional Monetary Policy—Recent Experience and ProspectsBackground Paper," IMF Policy Paper (Washington). http://www.imf.org/external/np/pp/eng/2013/041813.pdf

—_, 2013c, “2013 Spillover Report, IMF Multilateral Issues Report,” IMF Policy Paper (Washington). http://www.imf.org/external/np/pp/eng/2013/070213.pdf 
, 2013d, Fiscal Monitor, April 2013: Fiscal Adjustment in an Uncertain World, World Economic and Financial Surveys (Washington).

http://www.imf.org/external/pubs/ft/fm/2013/01/fmindex.htm

_, 2013e, "2013 Pilot External Sector Report, IMF Multilateral Issues Report," IMF Policy Paper (Washington). http://www.imf.org/external/np/pp/eng/2013/062013.pdf

_ , 2013f, "Global Impact and Challenges of Unconventional Monetary Policies," IMF Policy Paper (Washington). http://www.imf.org/external/np/pp/eng/2013/090313a.pdf

— $2013 \mathrm{~g}$, "Where the IMF Gets its Money" (Washington). http://www.imf.org/external/np/exr/facts/finfac.htm

Kahneman, Daniel, 2003, "Maps of Bounded Rationality: Psychology for Behavioral Economics," American Economic Review, Vol. 93 (December), pp. 1449-1475.

New York Times, 2008, "Central Banks Coordinate Global Cut in Interest Rates," http://www.nytimes.com/2008/10/09/business/09fed.html?pagewanted=all, October 8.

Official Monetary and Financial Institutions Forum, 2012, "Re-elected Obama May Take the Gloves off with Europe," http://www.omfif.org/intelligence/thecommentary/2012/november/re-elected-obama-may-take-the-gloves-off-with-europe/ November 13.

Reuters, 2013, "Global currency war could get nastier, warns Brazil's Mantega," http://www.reuters.com/article/2013/02/08/us-g20-brazil-euroidUSBRE9170N220130208, February 8.

Rey, Hélène. 2003, "Dilemma not Trilemma: The Global Financial Cycle and Monetary Policy Independence." Proceedings of the Federal Reserve Bank of Kansas City 2013, Economic Policy Symposium, Jackson Hole, WY.

Wright, David, 2014, "Strengthening the Global Financial Regulatory Architecture after the Crisis" in How Are Emerging and Developing Countries Affected by Monetary and Regulatory Spillovers from Advanced Economies, Conference Report on a HighLevel Roundtable on Finance, Global Economic Governance Program, University of Oxford held on February 12, 2014. 